\title{
HUMANISME PROGRESIF DALAM FILSAFAT PENDIDIKAN ISLAM
}

\author{
Wedra Aprison \\ Sekolah Tinggi Agama Islam Negeri (STAIN) Bukittinggi \\ Jl. Raya Gurun Aur Agam Sumatera Barat \\ Email: wedra.aprison@yahoo.co.id
}

\begin{abstract}
ABSTRAK
Tulisan ini berupaya menyederhanakan aliran-aliran filsafat pendidikan ke dalam tiga aliran saja yaitu konservatisme, liberalisme, anarkisme dan meretas jalan yang memungkinkan filsafat pendidikan Islam berperan di dalamnya. Caranya dengan mencari titik singgung di antara ketiga aliran tersebut kemudian menganalisisnya dalam konteks ajaran Islam. Mereka bertemu dalam konsep religiusitas/tauhid dan humanisme/amal shaleh. Ketika kedua konsep tersebut dihadapkan pada persoalan pendidikan dan kemasyarakatan, muncul tantangan baru bahwa filsafat pendidikan Islam kecuali harus religius dan humanis juga harus progresif dalam memajukan peradaban melalui semangat kebangsaan dan menghargai keragaman dalam suatu bangsa atau antar bangsa. Hasil sintesis tersebut dinamakan filsafat pendidikan Islam humanisme progresif. Metode yang digunakan dalam tulisan ini adalah analisis konten. Pemikiran filsafat pendidikan yang dianalisis adalah pemikiran O'neil tentang ideologi-ideologi pendidikan. Pemikiran teologi yang dijadikan landasan analisis adalah pemikiran Abu Zaid (2003) yang di Indonesia dibumikan oleh Setiawan (2012) sebagai Islam Progresif.
\end{abstract}

Kata kunci: Humanisme, Progresif, Filsafat Pendidikan Islam

\section{ABSTRACT}

This paper tries to simplify the schools of philosophy of education into three mainstreams only: constructivism, leberalism and anarchism, it is also to pave the way that enables philosophy of Islamic education play its role by finding out the interplay among those three mainstreams and then analysing them in the context of Islam. Those three share the same conceptions regarding religiosity/tawheed and humanism/good deeds. When the two points are confronted with the issues of education and community, new challenges emerge: that is, the philosophy of Islamic education except religious and humanist must also be progressive in advancing civilization through the spirit of diversity that exists within a nation or between nations. Philosophically, the result of the synthesis is called progressive humanism philosophy of Islamic education. The approach and methods used in this paper is a content analysis of the philosophical and theological education. Philosophical education analyzed is O'neil thought about educational ideologies. Theological analysis used as tool of analysis is Abu Zaid's thought (2003) regarding the importance of reasoning power of the word of God which is then grounded by Setiawan (2012) as a Progressive Islam.

Keywords: Humanism, Progressive, Philosophy of Islamic Education 


\section{PENDAHULUAN}

Secara internal, dunia pendidikan Islam pada dasarnya masih memiliki masalah yang cukup besar yaitu berupa rendahnya kualitas sumber daya manusia, terutama para pengelola pendidikan. Hal ini berhubungan dengan kualitas lulusan tenaga pendidik dan kependidikan yang dihasilkan oleh lembaga penghasil tenaga pendidik dan kependidikan Islam (Fakultas Tarbiyah dan Keguruan STAIN, IAIN dan UIN) di Indonesia yang masih rendah (Rahim, 2001: 14). Daya kreativitas lulusan dari lembaga pendidikan dan tenaga kependidikan Islam umumnya rendah. Persoalan-persoalan sosial, budaya, politik dan teknologi yang menimpa dunia pendidikan, cenderung diselesaikan secara normatif keagamaan daripada kritis, logis dan kreatif. Contoh, penggunaan internet untuk siswa masih dicurigai dapat mempermudah siswa mengakses situs porno daripada dianggap sebagai peluang untuk mendapatkan informasi dan pengetahuan aktual yang harus dikritisi. Akhirnya, kesan yang muncul dibenak publik (para orang tua terdidik) tetap saja menganggap bahwa pendidikan Islam masih tertinggal dari pendidikan umum. Berarti, ada hambatan teologis yang menyebabkan para pendidik dan tenaga kependidikan Islam kurang percaya diri dalam mengeksploitasi semaksimal mungkin daya nalar dirinya maupun dalam memberdayakan kemampuan berpikir anak didiknya.

Secara eksternal, pengelolaan pendidikan Islam dipengaruhi oleh tiga isu besar yaitu globalisasi, demokratisasi dan liberalisasi. Globalisasi tidak sematamata mempengaruhi perdagangan tetapi juga sistem pendidikan. Osman Bakar setidaknya telah membuat delapan daftar aspek positif globalisasi dan tiga belas aspek negatifnya. Delapan aspek positif globalisasi tersebut yaitu; 1) peranan perusahaan asing dalam menciptakan lapangan kerja dan mengurangi kemiskinan di berbagai negara (berkembang), 2) peningkatan mobilitas sosial dan memperkokoh kedudukan kelas menengah, 3) adanya peluang yang lebih luas untuk mendapatkan informasi dan menyebarkan ilmu pengetahuan berkat teknologi baru komunikasi dan informasi, 4) mempermudah dan menurunkan biaya komunikasi warga dunia, 5) membuka peluang yang lebih luas dalam berinteraksi bagi seluruh umat manusia dengan berbagai latarbelakang etnik, budaya dan agama, 6) membuka akses bagi seluruh umat manusia di dunia untuk bersimpati dan berempati terhadap korban bencana alam maupun tragedi yang diakibatkan oleh perbuatan manusia, 7) membuka saluran bagi penyebarluasan gagasan maupun tindakan yang dianggap baru dan baik terutama dalam bidang politik pemerintahan seperti akuntabilitas kinerja pemerintahan suatu negara, sosialisasi peraturan dan perundangan-undangan serta pelaksanaan hak-hak asasi manusia dan 8) menuntut dilaksanakannya hak-hak asasi perempuan (Osman Bakar, 2002: 123-124).

Aspek negatif dari globalisasi menurut Osman Bakar adalah 1) kualitas lingkungan yang semakin rendah sebagai dampak dari manusia yang terlalu berorientasi pada keuntungan, 2) pembangunan menjadi tidak seimbang karena ada kesenjangan ekonomi yang semakin lebar antara daerah kaya dengan daerah 
miskin pada suatu negara dan antara negara berkembang/miskin dengan negara maju, 3) pengabaian hajat hidup rakyat miskin di banyak negara, terutama di negara-negera selatan (Banglades dan Pakistan), 4) perputaran modal jangka pendek terlalu cepat karena muncul perilaku baru yang menjadikan uang sebagai komoditi perdagangan/valas, 5) pengangguran semakin bertambah dan munculnya kesenjangan baru yaitu perbedaan pendapatan yang lebar di negaranegara utara, 6) penyebaran beragama budaya yang belum tentu berguna dan bertentangan dengan tuntutan nilai kerohanian, moral serta merendahkan martabat kemanusiaan, 7) ada kecendrungan terbentuknya suatu budaya global yang homogen yang diperankan oleh lembaga-lembaga trans-nasional dan media komunikasi global, 8) terlalu gencarnya penyebaran budaya pop Amerika yang di satu sisi "menyegarkan panca indera" namun di sisi lain mematikan "penginderaan batiniah", 9) ada kecenderungan lembaga-lembaga pendidikan tinggi lebih mengutamakan program studi administratif dan teknis daripada program studi ilmu-ilmu kemanusiaan dan keagamaan, 10) membanjirnya informasi yang tidak berguna, 11) ada kecenderungan orang-orang Amerika Serikat dan beberapa negara Eropa memanipulasi isu-isu demokrasi dan hak-hak asasi manusia dalam rangka mendominasi politik dunia, 13) sulit membendung upaya meng-internasionalisasi/me-westernisasi hukum positif atas hukumhukum Islam, 13) sulit membendung semakin cepatnya wabah penyakit menyebar ke seluruh dunia (Osman Bakar, 2002: 25).

Kecuali isu globalisasi, isu lain yang mempengaruhi dunia pendidikan termasuk pendidikan Islam di Indonesia adalah isu demokrasi. Tuntutan demokrasi yang pada awalnya ditujukan hanya pada upaya perubahan dan perbaikan sistem politik negara yang otoriter mengarah pula kepada sistem perombakan sistem pengelolaan pendidikan. Jika sebelumnya sistem pendidikan lebih bersifat sentralistik, seragam dan dependen, maka belakangan muncul tuntutan untuk menerapkan sistem pengelolaan pendidikan yang lebih otonom dan desentralistik sehingga otoritas lokal penyelenggara pendidikan semakin diberi peran (Letch dalam Skilbeck, 1984: 31). Daerah diberi keleluasaan mengelola pendanaan (Bantuan Operasional Sekolah) sekolahnya. Berarti sekolah termasuk juga madrasah dituntut agar mampu mengelola pendanaannya secara akuntabel (Fahrurrozi, 2012: 225). Dampaknya, tuntutan partisipasi masyarakat khususnya dalam pengawasan mutu pendidikan semakin meningkat. Masyarakat menuntut pengelolaan pendidikan yang transparan dan bertanggungjawab. Paradigma demokratisasi dalam pembelajaran menggeser paradigma pembelajaran yang berpusat pada guru menjadi lebih berpusat pada siswa dengan menekankan agar siswa didorong untuk aktif dalam belajar. Maka di Indonesia muncul KTSP yang pada tahun 2013 ini akan segera diganti dan Manajemen Berbasis Sekolah (Suparno, 2012: 6). Dampak dari demokratisasi pendidikan adalah munculnya liberalisasi dan kapitalisasi pendidikan. Di level perguruan tinggi sempat terjadi upaya komersialisasi pendidikan yakni dengan adanya BHMN dan pada level sekolah dasar terdapat RSBI (Rintisan Sekolah 
Bertaraf Internasional) yang membolehkan pihak penyelenggara pendidikan 'memperdagangkan' kualitas pendidikan sesuai dengan keinginannya. BHMN saat ini telah tiada dan RSBI pun diancam oleh Mahkamah Konstitusi untuk dihapuskan karena disinyalir tidak manusiawi, diskriminatif dan melanggar hakhak asasi warga negara Indonesia untuk mengenyam pendidikan bermutu.

Sejumlah masalah di atas menunjukkan bahwa secara filosofis, perlu ada nilai-nilai dasar lain yang dapat mengimbangi nilai-nilai kapitalis, unbumanism 'tidak manusiawi' dan sekular dalam penyelenggaraan pendidikan. Artikel ini berupaya menawarkan nilai dasar humanisme Islam sebagai acuan normatif penyelenggaraan pendidikan dewasa ini yang atas nama profesionalisme, di satu sisi cenderung mengabaikan kehadiran tuhan dan di sisi lain 'menolak spirit ikhlas' dalam kerja mendidik murid.

Metode telaah yang digunakan dalam tulisan ini bersifat kualitatif dengan pendekatan filsafat Islam. Teknis analisis yang digunakan adalah analisis konten terhadap teks-teks filsafat pendidikan kemudian dipadukan dengan sejumlah pengamatan terhadap pelbagai fenomena sosial, budaya dan pemahaman keagamaan masyarakat Indonesia atas agama Islam yang berhadapan dengan isuisu kontemporer seperti globalisasi, demokrasi, hak asasi manusia dan gender.

\section{PEMBAHASAN}

\section{Humanisme Filsafat Pendidikan Kontemporer}

Dalam dua sampai tiga dekade terakhir ini ideologi-ideologi klasik seperti kapitalisme, sosialisme dan nasionalisme mulai kehilangan momentumnya, seiring dengan munculnya ideologi kontemporer seperti feminisme, pluralisme dan postmodernisme. Dalam bidang pendidikan, keriuhan tampak dengan munculnya sejumlah ideologi baru yang menawarkan doktrin pendidikan sebagai terapi atas krisis yang melanda dunia pendidikan. Di satu sisi hadirnya ideologiideologi tersebut memperkaya khazanah pemikiran pendidikan, tetapi di sisi lain bisa membingungkan para perencana, pengelola dan praktisi pendidikan.

William O’Neil dalam Knight (1982: 16) memetakan bahwa ideologi dalam pendidikan itu pada dasarnya ada dua aliran yaitu ideologi konservatif dan ideologi liberal. Ideologi-ideologi yang termasuk dalam ideologi konservatif adalah fundamentalisme, intelektualisme dan konservatisme. Ideologi-ideologi yang termasuk dalam ideologi liberalisme adalah liberalisme itu sendiri, liberasionisme dan anarkisme ${ }^{1}$. Giroux juga memetakan ideologi pendidikan menjadi tiga yaitu aliran konservatisme, liberalisme dan aliran Kritis (Giroux, 1981: 18).

Filsuf lain yang juga memetakan filsafat pendidikan adalah Brubacher. Menurut Brubacher filsafat pendidikan pada dasarnya dapat dibagi ke dalam dua kelompok besar yaitu filsafat pendidikan progresif dan filsafat pendidikan konservatif. Filsafat pendidikan progresif didukung oleh filsafat pragmatisme Dewey dan filsafat romantik naturalisme dari Rousseu. Filsafat pendidikan 
konservatif didasari oleh filasafat idealisme, realisme humanisme dan supranaturalisme atau realisme raligius. Aliran tersebut melahirkan filsafat-filsafat pendidikan di antaranya esensialisme dan perenialisme (Sadulloh, 2007: 96).

Antara O’Neil, Giroux dan Brubacher, secara umum, pemetaan mereka terhadap ideologi pendidikan memiliki persamaan. Mereka membaginya ke dalam dua aliran besar yakni konservatifisme dan liberalisme/progresivisme. Di antara dua aliran tersebut ada aliran lain yang merupakan sintesis atas keduanya, yakni anarkisme dalam pemetaan O'Neil dan aliran kritis dalam pemetaan Giroux. Brubacher tidak memberikan sintesis yang jelas, akan tetapi berdasarkan buku Sadullah- dapat dipahami bahwa ada orientasi lain dalam filsafat pendidikan yang sepadan dengan anarkisme maupun aliran kritis yaitu rekonstruksionisme.

Pada dasarnya ideologi pendidikan baik konservatisme, liberalisme, anarkisme, kritisisme, maupun rekonstruksionisme adalah humanisme, tentu dengan gayanya masing-masing. Humanisme konservatisme dapat ditelusuri dengan cara mengeksplorasi jejak filsafat idealisme. Humanisme liberalisme dapat ditelaah dengan membongkar akar filsafat materialisme. Humanisme kritisisme dapat didekati dengan konteks religius.

\section{Humanisme Konservatif}

Filsafat idealisme merupakan salah satu pandangan filsafat yang paling tradisional. Plato-lah yang mengembangkan formulasi klasik prinsip-prinsip filsafat kaum idealis. Kaum idealis umumnya mengklaim bahwa realitas tertinggi itu lebih bersifat spiritual dan mental daripada fisik dan material. Bagi mereka alam semesta adalah sebuah ungkapan kecerdasan dan kehendak suatu jiwa yang bersifat univerasal. Dunia adalah gagasan, abadi, permanen, teratur dan memberikan vitalitas serta dinamisme yang tinggi (Patrick, 2008: 54). Oleh sebab itu, kebenaran dan apa pun nilai kehidupan harus dikembalikan ke ranah dunia absolut dan universal pula. Hegel kemudian mengembangkannya dengan menciptakan sebuah pandangan dunia ideal yang hadir bersama-sama dengan dunia historis, sehingga filsafat Hegel lebih membumi meskipun di ujung (Geist) sangat idealis (Stumpf, 1989: 333).

Dalam konteks pendidikan para murid dapat dianggap sebagai entitas spritual yang juga sebagai bagian dari semesta spritual yang lebih luas. Meskipun ada perbedaan di antara kaum idealis namun pada dasarnya mereka setuju bahwa semesta ini terbuat dari realitas spritual yang bersifat personal, individual, atau mikrokosmos sebagai bagian dari suatu keseluruhan semesta yang universal. Anak didik adalah bagian dari semesta ruhaniah tertinggi. Karena alasan ini pendidikan harus menanamkan suatu keakraban antara anak dengan elemenelemen spiritual dari alam. Pendidikan harus menekankan keharmonisan yang dibawa sejak lahir antara manusia dan alam/universe. Ketika anak mempelajari dunia fisik, ia tidak harus menganggapnya sebagai sebuah mesin besar yang digerakkan oleh energi semesta/ universe menjadi suatu proses yang bermakna dan 
bertujuan. Emerson dan Thoreau mengelaborasi konsep realitas idealisme ke dalam dunia pendidikan yang lebih pragmatis, bahwa idealnya pendidikan itu harus pragmatis. Froebel dan Harris, menggunakan idealismenya saat mendasari pendidikan dengan suatu sistem pengadministrasian yang ketat. Idealnya pendidikan itu teradministrasikan dengan tertib dan teratur (Orntein and Levine, 1985: 187).

Tugas utama para guru adalah membawa pengetahuan yang terpendam tersebut ke dalam kesadaran. Melalui pembelajaran, para murid secara bertahap akan memasuki pengertian yang lebih luas dari kesadaran mental. Sebagai suatu proses intelektual yang utama, belajar melibatkan pemanggilan kembali, recalling and working, yaitu memancing kelahiran ide-ide. Karena realitas bersifat mental, pendidikan seharusnya berkaitan dengan persoalan-persoalan konseptual, selain menerapkan prinsip-prinsip eksternal kepada murid, ia juga berupaya mengembangkan berbagai kemungkinan yang ada dalam individu/peserta didik untuk mencari suatu perspektif yang lebih absolut dari alam semesta/universe. Prinsip absolutisme inilah yang kemudian menandai bahwa idealisme menjadi konservatif. Semua harus dikembalikan pada harmoni yang statis, permanen, abadi, sempurna dan tetap. Meskipun mereka menyadari bahwa semua itu adalah ilusi namun mereka tetap berpegang pada prinsip bahwa pendidikan harus terus berupaya mendidik anak menuju kesempurnaan yang abadi.

\section{Humanisme-Liberalisme}

Pandangan liberalisme menekankan bahwa masing-masing individu diberikan kebebasan untuk pengembangan kemampuan, melindungi dan menjunjung tinggi hak-hak dirinya dan orang lain. Pandangan ini tak pelak lagi merupakan pembenaran bagi upaya manusia untuk mengeksploitasi secara total potensi material yang ada yang berwujud pada legalitas historis sistem masyarakat dalam memenuhi hajat hidupnya. Dalam masyarakat industri, dalil ini kemudian teraktualisasi dalam ideologi kapitalis. Ketenangan hidup dapat dicapai dengan cara memenuhi semua kebutuhan hidup dirinya, kelompoknya dan negaranya. Bahkan solusi untuk meredam konflik apa pun di antara bangsabangsa adalah dengan cara menenteramkan mereka dengan menjadikannya sebagai negara sejahtera (welfare state) (O'neil, 2002: 31-32).

Bertolak dari pengertian di atas, konsep pendidikan pun mestinya bertolak dari paradigma rasionalisme-individual yang berorientasi pada pemenuhan kesejahteraan manusia. Pendidikan, sedemikian rupa, dirancang untuk menyiapkan individu agar mandiri dan mampu memenangkan persaingan untuk memperoleh pekerjaan agar hidup menjadi lebih layak dan berkecukupan. Dalam prosesnya, pendidikan berupaya mendorong dan menumbuhkembangkan seefektif mungkin kreativitas, semangat inovatif dan optimalisasi kemampuan individu yang sanggup bersaing dalam iklim kapitalisme. Pendidikan adalah sarana untuk meningkatkan status sosial individu dan keluarga peserta didik di masa depan. Humanisme liberal disebut konservatif karena memegang teguh 
prinsip pasar bebas bahwa unsur-unsur pokok produksi barang dan jasa (termasuk jasa dunia pendidikan) ditentukan oleh pasar bebas. Pendidikan yang baik secara alamiah akan meluluskan alumni yang baik dan alumni yang baik secara alamiah pula akan memenangkan persaingan dalam mencipta dan memperoleh lapangan kerja. Akhirnya, pekerjaan yang baik akan memperoleh keuntungan yang sebesar-besarnya (O’neil, 2002: 301-302).

\section{Humanisme-Anarkisme}

O’Neil menegaskan bahwa anarkisme di satu sisi sejalan dengan liberalisme bahwa individu itu harus bebas akan tetapi di sisi lain kebebasan individu itu dikekang oleh lembaga perkongsian. Berarti individu masuk pada kemapanan yang lain yaitu kemapanan kelompok. Anarkisme berupaya membongkar kemapanan ini. Karenanya anarkisme itu anti kemapanan atas apa pun yang ada di sekitar individu. Kondisi ini membawa pada pemahaman bahwa anarkisme adalah kritisisme atau rekonstruksionisme dunia individu atas lingkungan sosialnya. Aliran ini memandang bahwa pendidikan tidak dapat dilepaskan dari upaya individu merekonstruksi sosial agar ia tidak terjebak pada konstruksi sosial yang suda ada/mapan. Mereka menghendaki perubahan struktur sosial, ekonomi, politik melalui pendidikan. Oleh karena itu, pendidikan difungsikan sebagai wahana mengkonstruk lingkungan sosial lama menjadi baru setelah sebelumnya dibongkar atau didekonstruksi. Tujuannya agar tercapai tatanan sosial yang lebih adil dan manusiawi dalam ruh kedinamisannya (O'neil, 2002: 482-483).

Tokoh-tokoh humanisme-kritisis ialah Ivan Illich (menulis "de Schooling Society"), Paulo Freire (menulis "Pedagogy for the Oppresed") dan Everett Reimer (menulis School is Dead). Walaupun mereka berbeda dalam memformulasikan gagasannya, tetapi mereka memiliki ide yang hampir sama. Inti ide mereka menegaskan bahwa pendidikan merupakan wahana yang sangat strategis untuk melakukan penyadaran bagi setiap individu maupun masyarakat atas hak-haknya. Oleh karena itu, pendidikan harus dapat memerdekakan dan membebaskan individu manusia, terutama generasi muda dari penindasan, kebodohan dan kemiskinan. Menurut mereka, sekolah-sekolah formal-konvensional yang ada sekarang ini tidak dapat menjalankan peran pembebasan dan pemerdekaan ini bahkan sebaliknya sering digunakan untuk melanggengkan kekuasaan (Sunardi, 2001: v-x).

\section{Jalan Humanisme-Religius}

Pemaparan di atas seolah menunjukkan bahwa ideologi-ideologi pendidikan kontemporer yang ada di Barat, semuanya beraroma sekularisme. Ada anggapan -terutama di kalangan ilmuwan pendidikan Islam- bahwa konservatisme, liberalisme dan anarkisme itu, seluruhnya identik dengan filsafat humanisme sekuler. Sejatinya, anggapan tersebut tidak seluruhnya benar. O'neil menunjukkan bahwa dalam konservatisme ada jalan religius yaitu religius Kristiani/pengikut Kristus/Nasrani. Nasrani ini meliputi Katolik dan Protestan. 
Konservatisme Protestan tergambar dalam Protestan ortodoks yang mengakui bahwa kebenaran itu terletak pada wahyu dan iman. Perwujudannya terdapat dalam tafsir-tafsir harfiah atas teks-teks Alkitab yang diterima. Dampaknya, mereka membela kebenaran yang didasarkan pada pengategorian moral yang 'hitam-putih'. Secara tipikal, mereka mengorientasikan hidupnya ke akhirat semata. Tujuan pendidikan dalam konservatisme religius Protestan adalah membangkitkan dan meneguhkan kembali cara lama yang dianggap lebih baik dibanding dengan masa sekarang. Ada romantisisme masa Amerika abad 19 yang dianggap sebagai masa idealisasi turunnya kitab suci di masa Alkitab. Pendidikan pertama-tama bertujuan melakukan proses regenerasi moral dengan bercermin pada kebaikan Kristen masa silam. Katolik konservatif terwujud dalam Thomisme (pengikut Santo Thomas Aquinas) yang beranggapan bahwa sasaran utama pendidikan/sekolah adalah pelestarian dan penerusan pola sosial dan tradisi keyakinan serta praktik keagamaan yang sudah mapan. Kemapanan ini dilandasi oleh pembangunan moral-ruhaniah yang bercirikan Al-Kitabiah dan Evangelis (dakwah agama) (O'neil, 2002: 106, 218 dan 249).

Liberalisme religius tergambar dalam etika cinta kasih (Do unto others) yang secara pragmatis bermuara pada kesempurnaan iman personal. Bagi kaum liberal religius seseorang bisa mengabaikan aturan apa pun yang penting tidak melanggar aturan seks. Aturan seks bisa dilanggar ketika tidak ada hal yang dapat memungkinkan melanggar seks itu, seperti terdamparnya seseorang di pulau seorang diri, karena ia tidak mungkin melakukan hubungan seks karena tidak ada manusia lain. Mereka berpendapat bahwa hal yang adikodratiah kebanyakan dapat dipertanggungjawabkan secara rasional dan ilmiah. Jika orang harus melakukan itu maka secara kategoris ia diperbolehkan melakukan yang lain. Di sini mereka cenderung mempercayai sedikit saja sangsi etis yang datangnya dari Tuhan. Mereka cenderung patuh pada prinsip-prinsip abstrak Ilahiyah daripada praktik-praktik tertentu yang kondisional. Mereka lebih percaya pada 'tujuan' daripada 'cara' (O’neil, 2002: 396-397 dan 400). Berhubungan dengan ini, Kiekegaard menegaskan bahwa keimanan adalah pengalaman individual bukan konvensi tradisi (a conventional figure of tradition). Rumus ini mengacu pada situasi eksistensial Abraham saat mengorbankan anaknya yang secara konvensi tidak masuk akal karena harus patuh pada norma umum namun secara religius individual harus dilakukan karena itu perintah Tuhan (Roubiczek, 1966: 58-59).

Anarkisme religius tergambar dalam pemikiran Tolstoy. Ia menegaskan bahwa jika manusia mengikuti sifat hakiki mereka sendiri, yang pada dasarnya bersifat Ilahiyah (memantulkan hukum Tuhan), maka secara alamiah manusia akan peduli terhadap orang lain dan bekerja sama dengan sesamanya. Manusia tidak akan pernah menindas manusia lainnya. Pendidikan pun diarahkan dalam rangka menciptakan sealamiah 'otentik' mungkin. Individu sebagai hasil pendidikan yang otentik pasti seorang moralis. Ia pasti berkomitmen dalam menciptakan dunia yang lebih berperikemanusiaan (O’neil, 2002: 440). 


\section{Respons Filsafat Pendidikan Islam}

Pengaruh konservatisme, liberalisme dan anarkisme dalam pendidikan Islam saat ini berada dalam suatu 'loncatan'. Nilai-nilai transendental dan universal yang saat ini ditawarkan olah sebagian ideologi pendidikan Islam lebih bersifat reaksioner daripada paradigmatik. Para filsuf pendidikan Islam mengkritisi ketiga aliran di atas dalam konteks oposisi sekulerisme semata-mata, bahkan cenderung menempatkan mereka dalam kerangka ateisme yang dangkal. Padahal secara historis-paradigmatik ada persinggungan nilai-nilai Islam dengan ketiga aliran filsafat pendidikan di atas dalam jalan religius. Bahkan secara historis, persinggungan pemikiran filosofis itu telah terjadi berabad-berabad yang lalu saat filsafat Islam menginspirasi renaisans Eropa. Tentu, hal ini bukan semata hendak bernostalgia belaka, tetapi sekurang-kurangnya dapat mengurangi menguatnya kecenderung pengakuan yang dangkal pada beberapa pemikiran pendidikan Islam yang menganggap dirinya sebagai resep terakhir dalam memecahkan masalah pendidikan dewasa ini. Mungkin lebih bijak, ketika gagasan humanisme religius Islam sebagai gerakan melintas kembali ke dasar (cross back to the basic) filsafat pendidikan Islam.

Konservatisme religius Katolik dan Protestan yang memandang bahwa semua hal yang aktual dan relevan tidak perlu diubah, sebanding dengan aliran teologi Jabariah (Jahmyah) yang dipelopori oleh Al-Ja'd Ibn Dirham (abad VIII M). Aliran ini mengatakan bahwa manusia pada dasarnya tidak dapat mengubah situasi sosial. Semua sudah ditentukan oleh Allah SWT. Berarti semua perbuatan manusia sudah diciptakan Tuhan dalam diri manusia. Jika seseorang atau sekelompok orang itu ada yang miskin, bodoh, tertindas itu karena ketiadaan daya pada diri mereka sendiri. Manusia tak ubahnya seperti wayang yang tidak bergerak kalau tidak digerakan oleh dalang (Nasution, 2002: 33 dan Mu'in, 1992: 101). Dalam konteks moral, mereka enggan memperjuangkan nasibnya jika harus melakukan konflik. Mereka berpendirian lebih baik pasrah dan konaah. Filsafat pendidikan Islam konservatif tergambar dalam pemikiran al-Ghazali yang mengatakan bahwa tujuan pendidikan semata-mata untuk mendekatkan diri kepada Allah SWT (Nata, 2005: 212). Dengan mendekatkan diri manusia kepada Allah SWT maka nasib hidup pun akan Allah tentukan menjadi baik. Sebaliknya ketika manusia menjauh dengan Allah maka nasib buruk akan menimpanya.

Liberalisme religius Barat (Katolik dan Protestan) sebanding dengan aliran teologi qadariah yang dipelopori oleh Ma'bad Al-Juhani dan Ghailan Al-Dimasyqi (abad VIII M). Menurut paham mereka manusialah yang mewujudkan perbuatan-perbuatannya dengan kemauan dan tenaganya. Manusia dalam paham qadariah mempunyai kebebasan dalam kemauan dan kebebasan dalam perbuatan (Nasution, 2002: 33). Dalam konteks filsafat pendidikan Islam, aliran qadariah sejalan dengan filsafat pendidikan Ibnu Khaldun (abad ke 13 M) yang mengatakan bahwa pendidikan dipengaruhi oleh peradaban ciptaan manusia bahkan pendidikan baginya ditujukan dalam rangka membangun peradaban. 
Perbedaan status sosial timbul dari hasil kecerdasannya yang diproses melalui pengajaran (Nata, 2005: 223-225).

Berarti adanya anggapan bahwa sekarang ini telah terjadi liberalisasi pendidikan Islam oleh Barat tidak sepenuhnya benar. Sebaliknya, bahwa religiusitas-ideal ketuhanan dalam pendidikan dianggap murni milik Islam, juga tidak benar. Kontak peradaban keagamaan telah berlangsung sejak lama. Dalam masa Islam keemasan, kontak itu telah terjadi. Munculnya paham teologi Mu'tazilah disinyalir oleh Nasution sebagai buah dari adanya kontak peradaban Islam dengan peradaban Yunani (Nasution, 2003:32). Sebaliknya benih renaisans Barat dapat tumbuh karena ada kontak antara Ibn-al-Haitham (965-1020 M) dengan Roger Bacon dan Kepler serta antara Al-Ghazali dengan Thomas Aquinas dan (Cohen, 1989: 75-78).

Agama telah berkembang sejak lama dan dipeluk oleh berbagai komunitas yang sangat beragam dan kompleks. Hal ini meniscayakan adanya dialektika antara ajaran Islam dengan kondisi zaman dan budaya lokal yang ada sehingga menghasilkan pemahaman agama yang di satu sisi fungsional, dapat berlaku dalam lingkup pemeluknya namun di sisi lain universal. Sebagian realitas kehidupan mutakhir tidak mendapatkan penjelasan yang cukup tegas dalam teks kitab suci agama. Padahal, jawaban agama atas masalah yang baru muncul sangat diperlukan. Berhubungan dengan ini, humanisme religius Islam tidak bisa dicurigai sebagai reaksi tetapi juga sebagai tuntutan zaman, baik dalam perspektif konservatif maupun dalam perspektif liberal. Dalam perspektif liberal tumbuh kesadaran perlunya penafsiran secara kreatif atas teks-teks suci al-Qur'an sejauh konsisten dengan nilai-nilai dasar yang dikandungnya. Liberalisme Islam religius sewajarnya dipandang sebagai penegas adanya kaidah bahwa isu baru apa pun yang berkembang dewasa ini pada dasarnya memiliki relevansi dengan esensi ajaran Islam. Sebaliknya, perspektif konservatif, dalam menafsirkan kitab suci, tidak boleh mengklaim dirinya sebagai satu-satunya pemilik sah atas teks alQur'an yang suci tersebut, sekalipun berlandaskan pada isu-isu yang memang terjelaskan secara eksplisit di dalamnya (mubkamat). Bagaimana pun, pengklasifikasian teks ini atau itu mubkamat atau tidak bergantung pada sudut pandang apa dan siapa yang menafsirkan (Musa, 1991: 51). Ada ruang abu-abu dalam tafsir kitab suci. Ruang abu-abu itu membuka jalan bagi kritisisme religius dalam filsafat pendidikan Islam. Ruang abu-abu tersebut tetap dihuni oleh konsep taubid. Namun sebelum konsep tauhid disahkan mengisi aliran kritisisme religius, ia harus masuk ke dalam ranah humanisme pendidikan Islam terlebih dulu, sampai ia sah menjadi ideologi jalan tengah pendidikan Islam.

\section{Humanisme Filsafat Pendidikan Islam}

Alat untuk memperdebatkan bahwa tauhid itu humanis atau tidak, adalah akal. Dalam perspektif konservatisme, akal tidak boleh dimutlakan. Orang yang memutlakan akal, bagi mereka disamakan dengan kaum komunis. Dalam pandangan konservatif (fundamentalis), kaum komunis adalah orang yang 
menggunakan (menuhankan) akal pikirannya secara mutlak karena mereka yakin bahwa akal itu sanggup menemukan kebenaran, bahkan mampu sampai pada kebenaran terakhir. Bagi mereka, determinisme ekonomi adalah puncak kemusyrikan akal yang menganggap bahwa Tuhannya adalah uang dan harta kekayaan. Bagi kaum konservatif kebenaran yang diperoleh akal hanyalah kebenaran insani dan karena itu terkena sifat relatifnya manusia. Maka menurut mereka, sakalipun rasio dapat menemukan kebenaran namun kebenarannya relatif. Bagi mereka, kebenaran yang mutlak hanya dapat diperoleh melalui jalan lain yang lebih tinggi daripada rasio, yaitu wahyu. Dalam konservatisme, keyakinan bahwa relativisme akal itu negatif dianggap penting agar tidak terjebak pada subjektivisme mutlak-mutlakan (Rasjidi, 1975: 23). Keterbatasan kemampuan rasio dan keharusan manusia untuk menerima sesuatu yang lebih tinggi daripada rasio dalam rangka mencari kebenaran itu mereka dasarkan pada firman Allah "Kamu manusia tidak diberi ilmu pengetahuan (melalui rasio) melainkan sedikit saja" (QS. Al-Isrâ [17]: 85 dalam Junus, 2000: 263). Dalil ini diperkuat dengan pernyataan Einstein bahwa seluruh pengetahuan kita tentang alam raya hanyalah semata-semata residu dari kesan-kesan yang diselubungi oleh akal pikiran kita yang tidak sempurna. Hal ini membuat upaya pencarian kenyataan (kebenaran) itu tidak bisa diharapkan lagi. Bagi mereka ini bukti bahwa kesadaran (akal pikiran) itu terbatas. Di sini mereka meyakini bahwa Einstein memasuki alam keinsyafan keagamaan yang mendalam. Simpulan ini ditarik dari pernyataan Einstein bahwa ilmu tanpa agama buta dan agama tanpa ilmu lumpuh (Suriasumantri, 1982: 3). Bagi kaum konservatif, kebahagiaan manusia ditempuh melalui empat tahap kehidupan ${ }^{2}$. Pertama ialah tahap naluriah. Pada tahap ini manusia lahir kemudian hidup di dunia. Kedua ialah tahap panca indera. Tahap indera ini menyempurnakan tahap naluriah meskipun belum sempurna, sebab indera masih sering membuat kesalahan. Tahap ketiga adalah tahap akal pikiran. Tahap ini mengoreksi kesalahan-kesalahan yang dibuat pada tahap indera. Pada tahap rasio kemampuan manusia masih terbatas. Tahap keempat adalah tahap wahyu. Tahap ini manusia mencapai kebahagian sejati. Manusia sampai kepada kebenaran terakhir. Pada tahap ini, tuhan mengajari manusia melalui wahyu yang disampaikan kepada para nabi dan rasul yang dipilih di antara manusia yakni wahyu terakhir (al-Qur'an). Maka secara konservatif, mereka mengklaim Islam sebagai kebenaran terakhir (QS. Al-Maidah [5]: 3). Keempat tahap jalan hidup manusia bagaikan anak tangga yang masing-masing saling menopang. Naluri, indera, rasio dan wahyu (agama) tidak saling mendahului karena itu tidak ada pertentangan antara naluri dengan indera yang dikendalikan oleh akal dan akal yang dibimbing oleh wahyu.

Bagi kaum liberal, ada masalah yang jauh lebih kongkret daripada hanya dengan selalu bersikap mapan atau objektif. Manusia hidup tidak seperti hukum perlistrikan, yang dapat digeneralisir dayanya dengan ampere atau volt. Perilaku manusia yang bergaul baik dengan dirinya sendiri maupun dengan orang tidak mungkin melepaskan diri dari kerangka kebebasan dan subjektifismenya karena 
ada praanggapan-praanggapan yang memenuhi pikirannya. Ketika manusia mengamati dirinya, merumuskan hukum-hukum tentang hubungan antara diri dengan sesama, dia tidak sanggup lagi bersikap objektif secara mutlak. Hukumhukum yang disimpulkan oleh manusia tentang manusia sendiri, bagaimana pun tidak seluruhnya benar. Ada perbedaan penafsiran antara ilmuwan satu dengan ilmuwan lain tentang individu, sistem sosial, pendidikan, ekonomi, politik, yang mengatur kehidupan manusia sebagai makhluk organis.

Dalam konteks religius, liberalisme Islam memandang bahwa ketika rasio/akal manusia itu tidak sanggup menemukan kenyataan terakhir tentang materi maka tidak mungkin manusia dapat menemukan hal-hal yang bukan material seperti masalah ruh, malaikat dan alam ghaib. Karena itu relativisme tidak hanya melekat pada akal saja tetapi pada wahyu yang dipahami oleh akal. Maka masuk akal agar wahyu dapat dipahami oleh akal manusia harus menggunakan akalnya (Madjid, 1998: 181). Al-Muhasibi memandang bahwa akal adalah naluriah (ghazirah) yang juga diberikan Allah kepada manusia dalam rangka mengkaji inti suatu persoalan termasuk persoalan-persoalan yang terdapat dalam al-Qur'an (Zaid, 2003: 88-89). Abu Zaid memposisikan manusia sebagai pembaca yang kritis yang mampu menembus inti permasalahan bentuk wahyu ketika menjadi tulisan, simbol bunyi bahasa, penafsiran dan perilaku keberagamaan umat Islam (Setiawan, 2008: 17).

Humanisme anarkis religius dalam pendidikan Islam memandang bahwa kecuali akal, rasa juga menjadi penting dalam membentuk manusia seutuhnya (kâffah). Perpaduan antara akal dengan rasa itu disebut tauhid. Konsep tauhid, menjadi dasar ajaran Islam bukan hanya karena seseorang harus percaya terhadap Tuhan yang satu tetapi karena al-Qur'an menyerukan agar manusia itu beriman (bertuhan satu) sekaligus beramal shaleh. Dalam QS. Al-Baqarah, [2]: 2 dinyatakan bahwa orang Islam yang akan mencapai derajat muttaqin harus beriman, mendirikan shalat dan menunaikan zakat (trilogi iman-sholat-zakat) serta berilmu dan beramal shaleh (trilogi iman-ilmu-amal) (Kuntowijoyo, 1998: 167). Iman dan Islam berujung pada amal/aksi. Artinya, nilai tauhid Islam bukan hanya bertuhan tetapi harus mengaktualisasikan prinsip-prinsip dasar ajaran ketuhanannya. Pusat iman dan Islam adalah Tuhan, tetapi ujung aktualisasinya adalah manusia. Dengan demikian, Islam menjadikan tauhid sebagai pusat dari semua orientasi nilai, sementara pada saat yang sama melihat manusia sebagai tujuan dari transformasi nilai. Dalam konteks inilah Islam disebut rabmatan lil alamîn. Berarti, konsep tauhid adalah sebuah humanisme. Tauhid adalah mementingkan manusia sebagai tujuan sentral. Tauhid memusatkan dirinya pada keimanan terhadap Tuhan dan pada saat yang bersamaan mengarahkan perjuangannya untuk kemuliaan peradaban manusia. Prinsip humanisme tauhid inilah yang mendasari anarkisme religius dalam filsafat pendidikan. Atas dasar nilai humanisme tauhid, pendidikan Islam memandang bahwa wahyu tetap sebagai inti ajaran pendidikan, namun sedemikian rupa ia digunakan untuk merangsang penggunaan akal dan panca indera (kemampuan mengamati) bahkan 
intuisi, agar peserta didik mampu menangkap setiap kebenaran wahyu yang selalu sesuai dengan perkembangan zaman dan mengarah pada kemajuan itu. Tiga aliran dasar filsafat pendidikan (konservatisme, liberalisme dan anarkisme) itu pada dasarnya memiliki dua kesejajaran. Pertama adalah kesejajaran humanisme dan kedua religius. Jika aliran anarkisme religius, secara filosofis ditelaah dan secara praktis dihadapkan dengan kenyataan kehidupan sekarang ini maka terdapat unsur progresivitas pada keduanya. Secara religius wahyu yang dilandasi humanisme mencerminkan nilai tauhid tersendiri, dalam bentuk ikhlas beramal dalam rangka beribadah kepada Tuhan. Secara filosofis wahyu/tauhid/agama dituntut agar dapat memecahkan persoalan umat. Sintesis ini menghadirkan paham lain yaitu humanisme progresif dalam pendidikan Islam. Sebutan religius terlingkupi dalam konsep Islam yang melekat pada konsep pendidikan Islam sehingga tidak perlu secara eksplisit disebut humanisme-religius progresif.

\section{Humanisme Progresif Filsafat Pendidikan Islam}

Humanisme progresif filsafat pendidikan Islam dasarnya adalah semangat mengintegrasikan ilmu umum dengan ilmu agama secara progresif. Caranya ilmu agama yang normatif dibuat menjadi deskriptif agar mudah dilaksanakan dan bermanfaat bagi kehidupan sehari-hari. Fiqih tidak hanya berpusat pada mengajarkan syariat yang berupaya dimutlakan secara universal sehingga ada kesan bahwa produk ulama masa lalu merupakan satu-satunya solusi untuk memecahkan masalah kontemporer saat ini. Sehingga tampak wajah fiqih yang dengan keras dan kaku memaksa setiap perilaku manusia zaman sekarang agar sesuai dengan perilaku manusia pada masa lalu (Madjid dkk., 2004: 7).

Menurut Qardhawi mestinya pengajaran fiqih direformasi dengan cara mengajarkan fiqih realitas (fiqh al-wâqi) dan fiqih prioritas (fiqh al-awlawiyât), yakni fiqih yang dijadikan sebagai sinaran baru bagi problem kemanusiaan yang muncul di tengah-tengah masyarakat saat ini. Syari'at diharapkan tidak lagi bercorak vertikal (hubungan manusia dengan Tuhan) semata tetapi juga bercorak horisontal (hubungan manusia dengan manusia). Dalam konteks ini fiqih didesak untuk menyentuh isu-isu kesetaraan gender 'fiqh al-mar'ab', ketatanegaraan 'fiqh aldawlah' dan fiqh kewarganegaraan ('al-muwâthanab'). Syari'at yang diajarkan bukan hanya hukum sebagai produk saja tetapi juga ditelusuri hingga ke tujuan-tujuan sebenarnya dari produk tersebut (maqâhsid al-syarîab) yakni dibuat untuk kemaslahatan umat manusia 'al-maslahat al-'ammah' (Madjid dkk., 2004: 7 dan 10).

Dalam konteks ilmu umum, kritisisme dan progresivisme muncul pada sosok Khayyam yang berupaya mengurai baik fisika maupun matematika tidak langsung masuk ke ranah teologi yang bersifat formal dengan memberi stempel bahwa matematikanya Islami atau tidak Islami. Hal yang dia lakukan membahas secara kritis substansi keilmuan matematik dengan demonstrasi matematika pula. Dalam Fi Syarb Ma Asykala min Mushadarat Kitab Uqlidus memuat kritik/pembahasan atas teori garis sejajar Euclide. Baru pada bagian lain 
Khayyam mengkritik teori paralel Euclide (Bakar, 1995: 171). Di sini Khayyam menunjukkan kualitasnya dalam bidang geometri. Ia tidak seperti intelektual Muslim sekarang yang tergesa-gesa, secara teologis (bukan substansi ilmunya itu sendiri) memvonis karya orang lain (Barat) sebagai islami atau bukan.

Khayyam menolak postulat kelima Euclide yang menggunakan sifat kesamaan jarak, padahal hampir semua matematikawan saat itu menerimanya tanpa reserve termasuk Haytsam dan Anaritius.

Jika sebuah garis lurus bergerak sedemikian sehingga ujung garis yang satu selalu menyentuh garis lurus kedua dan sepanjang gerak ini senantiasa tegak lurus dengan garis yang kedua dan berada pada bidang yang sama dengannya, maka ujung lain dari garis yang bergerak akan merupakan garis lurus yang sejajar dengan yang kedua (Sabra dalam DSB Vol VI: 201-202 dalam Bakar, 1995: 175).

Proposisi 29 Euclide berbunyi:

Sebuah garis lurus yang jatuh pada garis-garis lurus yang sejajar, membuat sudut pengganti yang sama besar satu sama lainnya, sudut luar sama dengan sudut dalam dan sudut lawan dan sudut-sudut dalam pada sisi yang sama, jumlahnya sama dengan dua kali sudut siku-siku (Bakar, 1995: 178).

Khayyam membuktikan bahwa kedua garis yang tegak lurus pada garis lurus yang sama tidak konvergen dan tidak pula divergen, karena keduanya berjarak sama 'equidistant' satu sama lain (Rosenvelt dan Youschkevitch, 1961: 329 dalam Bakar, 1995: 178).

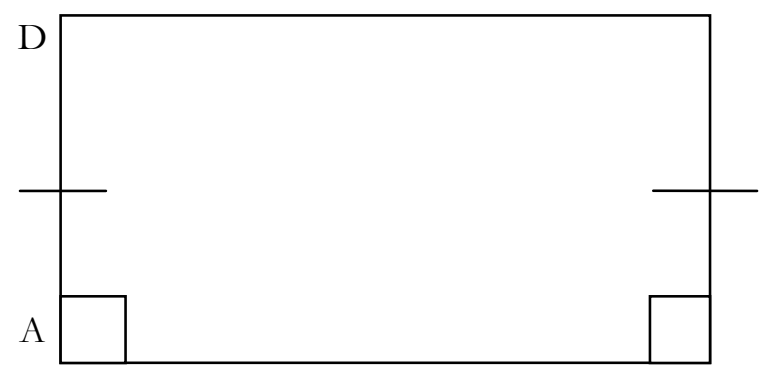

Khayam mengonstruksi proposisi I (bangun bersisi empat Saccheri) dengan cara dia mengamati empat persegi panjang ABCD, yang mana dua sisi $\mathrm{AD}$ dan $\mathrm{BC}$ sama panjang dan keduanya bersudut siku-siku terhadap sisi AB. Tanpa dengan postulat kelima, sudut ADC dan BCD adalah sama. Militansi Khayyam dalam bidang matematika menginspirasi pandangan progresif filsafat pendidikan Islam bahwa ilmu umum dengan ilmu agama itu pada dasarnya satu, kepunyaan Allah (tauhid). 
Selain Qur'an dan Sunnah yang dijadikan pijakan oleh aliran humanisme progresif filsafat pendidikan Islam, dasar lokal kenegaraan juga menjadi perhatian aliran ini. Islam pada dasarnya universal dan nilai universal Islam terdapat dalam dasar kenegaraan Indonesia yaitu Pancasila. Sistem pendidikan nasional di Indonesia pasti berideologi Pancasila. Namun, ideologi Pancasila tidak harus dipandang bertentangan dengan Islam. Secara tematis (al-maudu' $)$, nilai-nilai al-Qur'an teradopsi dalam Pancasila, meskipun tidak seluruhnya dan tidak mungkin seluruhnya. Konteks kesatuan dan persatuan Republik Indonesia yang terdapat dalam Pancasila bisa dijelaskan dalam ibrab Nabi Dawud dan Sulaiman pada QS. Al-Baqarah [2]: 251; QS. Al- Anbyâ [21]: 79; QS. Saba’ [34]: 10 dan QS. Shâd [38]: 26. Ayat-ayat tersebut menyinggung kewibawaan wilayah serta kekuatannya sebagai titik sentral dalam membangun suatu peradaban (Setiawan, 2012: 107-108). Progresivisme filsafat pendidikan Islam yang dibangun oleh Setiawan bukan sebatas mengajukan argumen normatif bahwa nilai Pancasila itu bersinggungan dengan nilai Islam saja, tetapi ada kenyataan bahwa institusi pendidikan Islam di Indonesia yang berada di bawah naungan Kementerian Agama sangat banyak jumlahnya, meliputi tiga puluhan lebih perguruan tinggi Islam negeri (belum yang swasta), ratusan pesantren dan ribuan madrasah baik yang negeri maupun swasta. Di sini ada keniscayaan bahwa lembaga pendidikan Islam harus menggunakan 'model' kajian keislaman yang bersifat keindonesiaan yang berbeda dengan Islam Arab (Timur Tengah). Bagaimanapun juga khasanah pendidikan Islam Indonesia itu menyejarah bersama-sama (koeksisten) dengan perjuangan seluruh rakyat Indonesia dalam rangka meraih kemerdekaan (Setiawan, 2012: 12-130. Maka selayaknya, saat ini pendidikan Islam Indonesia berkontribusi bersama dengan elemen keagamaan lain dalam meningkatkan harkat dan martabat bangsanya agar sejajar dengan bangsa-bangsa lain di dunia.

Indonesia adalah negara yang bhineka. Masyarakat Indonesia terdiri atas beragam budaya, agama, suku, bahasa. Ada sekitar 300 suku bangsa, 102 bahasa daerah dan 185 dialek bahasa lokal serta ratusan agama (kearifan) lokal (Sapriya, 2009: 152-153). Keragaman ciptaan Allah adalah sunatullah. QS. Hûd [11]: 118 menyatakan bahwa, 'Tikalau Tuban menghendaki, tentu Dia menjadikan manusia umat yang satu, tetapi mereka senantiasa berselisih pendapat”. QS. Al-Isrâ [17]: 84 pun menyatakan bahwa, "Katakanlah tiap-tiap orang berbuat menurut keadaannya masingmasing. Maka Tuhanmu lebih mengetahui siapa yang lebih benar jalannya".

Frasa, "jikalau Tuhanmu menghendaki" dalam QS. Hûd [11]: 118 dimaknai oleh para ahli tafsir sebagai pengandaian yang tidak memerlukan jawaban akan kenyataannya. Ini adalah gaya bahasa yang tidak memerlukan penegasan lebih lanjut. Dengan demikian, teks ini meniscayakan keragaman bagi umat manusia secara umum. Keragaman adalah salah satu jalan keagamaan. Kalimat, "tiap-tiap orang berbuat menurut keadaannya masing-masing" menekankan bahwa keberadaan individu yang melakukan aktivitas, berkarya, selaras dengan temuan, model, jalan 'minhaj', metode serta cara masing-masing melahirkan keragaman 
dalam pelbagai segmen. Tata nilai, pranata sosial, peraturan 'syirpah', adat istiadat, kebiasaan antara komunitas satu dengan komunitas lain berbeda. Perbedaan ini adalah suatu anugrah dari Allah SWT (Setiawan, 2012: 124-125).

Humanisme progresif filsafat pendidikan Islam tidak hanya menekankan keunikan dan otentisitas di antara individu tetapi juga menekankan adanya kebersamaan demi mencapai kemajuan di antara individu. Pendidikan dalam arti ini perlu diarahkan pada pencapaian kualitas individu yang kreatif sehingga perilaku anak didik tidak harus seragam, tetapi juga memperhatikan aspek menghargai hak-hak orang lain. Humanisme progresif dalam filsafat pendidikan Islam tidak mencetak manusia egois tetapi membentuk manusia kaffah yang terus bersinergi dalam keragaman. Tidak ada pemisahan unsur-unsur perorangan atau kolektif. Hal yang paling penting semua tersatukan dalam tujuan akhir manusia yaitu mengabdi kepada Tuhan. Praktiknya melalui perantara manusia. Jika manusia yang dihadapinya ridha maka Tuhan akan meridhainya pula. Prinsip ikhlas dalam beramal shaleh terhadap sesama menjadi kunci humanisme progresif pendidikan Islam (Boisard, A, Marcel, 1980: 166-167).

\section{SIMPULAN}

Aliran anarkisme dan progresivisme merupakan jalan tengah dari konservatisme dan liberalisme filsafat pendidikan. Ketiga aliran tersebut tidak seluruhnya sekuler sebab pada mereka hadir nuansa religius bahkan dalam anarkisme progresif itu sendiri. Berarti ada paham konservatisme religius, liberalisme religius dan anarkisme progresif religius. Dalam konteks filsafat pendidikan Islam muncul pula paham-paham seperti filsafat pendidikan Islam konservatif, liberal dan anarkis (progresif). Aliran-aliran tersebut, pada dasarnya juga humanis, tentu dengan gayanya masing-masing. Humanisme religius konservatif dalam pendidikan memandang bahwa pembelajaran itu diisi dengan upaya memperbaiki moralitas masyarakat seperti pada masa turunnya al Kitab. Humanisme religius liberal dalam pendidikan mengarahkan agar manusia memaksimalkan kesalehan individu dalam berhubungan dengan Tuhan. Humanisme religius anarkis dalam pendidikan bermaksud membuka potensi individu agar meraih keotentikan dirinya dalam menjalani hidup. Humanisme religius konservatif dalam pendidikan Islam mengajarkan bahwa manusia hendaknya pasrah kepada Allah SW'T agar manusia diberi nasib yang baik, baik di dunia maupun di akhirat. Humanisme religius liberalisme dalam pendidikan Islam berupaya membentuk manusia yang dapat memaksimalkan potensi akalnya. Humanisme religius anarkis dalam pendidikan Islam memandang bahwa tauhid menjadi jalan bagi manusia untuk beramal shaleh dengan ikhlas dan tulus agar mendapat ridha-Nya. Ada dua titik persinggungan antara konservatifisme, liberalisme dan anarkisme yaitu humanisme dan religiusitas. Dalam dua persinggungan tersebut terdapat spirit kerja kemanusiaan lain sebagai makhluk tuhan yang harus berupaya memecahkan dan memajukan kehidupan. Maka lahir paham humanisme progresif filsafat pendidikan Islam. Aliran ini berupaya 
mensinergikan antara tauhid dan humanisme universal dengan kebutuhan dan konteks lokal seperti kebhinekaan dan kebangsaan. Berarti, pendidikan dalam aliran humanisme progresif bertujuan menanamkan nasionalisme yang didasarkan pada nilai-nilai universal kemanusiaan dan ketuhanan.

\section{DAFTAR PUSTAKA}

Bakar, Osman. 1995. Taubid dan Sains: Esai-esai Sejarah dan Filsafat Sains Islam, Bandung: Pustaka Hidayah.

Bakar, Osman. 2002. Pengaruh Globalisasi terhadap Peradaban, dalam Al-Huda: Jurnal Kajian Ilmu-ilmu Islam, Jakarta: Islamic Centrer Al-Huda, Vol 2, no 7.

Boisard, A. Marcel. 1980. Humanisme Dalam Islam. Jakarta: Bulan Bintang.

Cohen, Bernard I, 1989. A History of Science. New York: Cambridge.

Fahrurrozi. 2012. Manajemen Keuangan Madrasah. Media Pendidikan Jurnal Pendidikan Islam, volume: XXVII, Nomor 2, 1433.

Girouk, H. A. 1981. Ideology and the Process of Schooling, Philadelpia: Temple University and Falmer Press.

Jorge R. Knight. 1982. Issue and Alternative inn Educational Philosophy, Michigan: Andrews University Press

Junus, Mahmud. 2000. Tarjamah Al Quran Al Karim. Bandung: Alma'arif.

Kuntowijoyo. 1998. Paradigma Islam: Interpretasi Untuk Aksi, Bandung: Mizan, cet. $\mathrm{Ke}-8$.

Letch, Ron. 1984. New Directions In Curriculum Policy, Local And National: Changes at Local Level. Dalam Skilbeck, Malcolm, Readings in School-Based Curriculum Development, London: Harper Education Series.

Madjid dkk. 2004. Fiqih Lintas Agama. Jakarta: Paramadina.

Mu'in Abd, Thahir, Taib. 1992. Imu Kalam. Jakarta: Widjaya.

Musa, Yusuf. 1991. Al-Qur'an dan Filsafat. Yogyakarta: Tiara Wacana.

Nasution, Harun. 2002. Islam Ditinjau Dari Berbagai Aspeknya, jilid II, Jakarta: Universitas Indonesia.

Nata, Abudin. 2005. Filsafat Pendidikan Islam, Jakarta: Gaya Media Pratama.

O’neil, William. 2002. Ideologi-Ideologi Pendidikan, Yogyakarta: Pustaka Pelajar.

Orntein, A. C. and Levine, D. U. 1985. An Introduction to Faoundation Education Chicago: Hougthon Miffin Compny Boston.

Patrick, White, Thomas, George. 2008. Pengantar Singkat Ilmu Filsafat, disadur oleh Irawan, Bandung: Intelekia Pratama.

Rahim, Husni. 2001. Arah Baru Pendidikan Islam di Indonesia, Jakarta: Logos

Rasjidi, H.M. 1975. Filsafat Agama. Jakarta: Bulan Bintang.

Roubiczek, Paul. 1966. Existentialism for and Against. New York: Cambridge

Sadulloh, Uyoh. 2007. Pengantar Filsafat Pendidikan, Bandung: Alfabeta.

Sapriya. 2009. Konsep Dasar Pendidikan Kewarganegaraan, Jakarta: Direktorat

Jenderal Pendidikan Islam Departemen Agama Republik Indonesia.

Setiawan, Nur Kholis. 2008. Pemikiran Progresif Dalam Kajian Al-Qur'an. Jakarta: Predana Media Group. 
Setiawan, Nur Kholis. 2012. Pribumisasi Al-Qur'an. Yogyakarta: Kaukaba Dipantara.

Stumpf, Enoch, Samuel. 1989. Philosopby History and Problems. Singapore: McGraw-Hill.

Sunardi, St. 2001. Paulo Freire: Dari Paedagogy of the Oppressed Menuju Paedagogy of the Heart. William A Smith, Conscientizacao Tujuan Pendidikan Paulo Freire, Yogyakarta: Pustaka Pelajar.

Suparno, Paul. 2012. Harapan Untuk Kurikulum Baru. Kompas Edisi Sabtu 29 September.

Suriasumantri, Jujun S. 1982. Ilmu Dalam Perpektif. Jakarta: Gramedia. Zaid, Abu, Hamid, Nashr. 2003. Menalar Firman Tuhan. Bandung: Mizan.

${ }^{1}$ Atau lihat O’Neil 2002, Ideologi-Ideologi Pendidikan, Yogyakarta: Pustaka Pelajar yang menjadi dasar filosofis kajian dalam paper ini.

${ }^{2}$ Lihat Tafsir Al-Maraghi jilid I. 